\title{
DESAIN MODUL PEMBELAJARAN MATEMATIKA DENGAN INSTRUKSI DAN SOAL SESUAI VARIASI INDIVIDU SISWA PADA MATERI SISTEM PERSAMAAN LINEAR
}

\author{
Lilis Rokhayah \\ SMKN 1 Bandung \\ lisro65@gmail.com
}

\begin{abstract}
ABSTRAK
Pembelajaran matematika dengan modul dalam penelitian dan pengembangan ini adalah untuk menuangkan seberapa efektifkah desain permasalahan matematika yang tertuang dalam soal matematika terhadap tingkat pemahaman konsep dan penalaran peserta didik. Guru perlu mengkaji preferensi belajar setiap peserta didik dengan memberikan pengajaran yang berbeda (differentiated instruction) pada setiap pembelajaran matematika yang diberikan di kelas. Penentuan desain dan penyajian soal dalam matematika merupakan kunci awal sebagai usaha guru meningkatkan kualitas dan penalaran peserta didik. Tujuan penelitian ini adalah mendesain modul pembelajaran matematika dengan instruksi dan soal sesuai variasi individu siswa pada kompetensi Sistem Persamaan Linear di level SMK. Penelitian ini berfokus pada bagaimana membuat instruksi dan desain soal dengan modul untuk meningkatkan pemahaman konsep variabel, prinsip mengubah bentuk, menafsirkan permasalahan dan model ke dalam sistem persamaan linear serta meningkatkan penalaran dan kelancaran berprosedur. Setiap peserta didik dapat memilih instruksi sesuai dengan minat, potensi yang dimiliki, keberagaman kecerdasan (multiple intelligences) dan aspek lain dari keunikan peserta individu didik. Setelah modul dibuat maka modul divalidasi oleh para ahli. Validasi dilakukan oleh 4 orang guru dengan kesimpulan yang diperoleh sangat baik. Selanjutnya dilakukan ujicoba produk. Uji coba dilakukan di kelas X Akuntansi sebanyak 4 kali dan Kelas XI Akuntansi sebanyak 2 kali. Kesimpulan dari hasil penelitian ini yaitu: (1) Penggunaan berbagai bentuk penyajian dengan modul pembelajaran merupakan sarana yang efektif ketika digunakan pada berbagai kelompok peserta didik yang memiliki banyak variasi individu dalam belajar matematika, (2) Penggunaan berbagai bentuk penyajian dengan modul pembelajaran menjadikan fleksibilitas untuk menterjemahkan bentuk matematika memudahkan peserta didik memperdalam pemahamannya terutama konsep, (3) Penyajian berbagai bentuk penyajian yang berbeda dengan modul pembelajaran memberi harapan dalam menyesuaikan cara berpikir dan penalaran peserta didik, (4) Prototip draf final dapat diperbanyak untuk menjadi bahan ajar di SMK, baik ditempat penelitian maupun tempat lain, (5) Pengembangan modul dapat dijadikan alternatif dalam pembelajaran matematika bagi guru untuk meningkatkan kemampuan komunikasi dan pemecahan masalah matematis peserta didik.
\end{abstract}

Kata Kunci: Modul, differentiated instruction, variasi.

\begin{abstract}
Learning mathematics with modules in this research and development is to express how effective mathematical problems design which contained in mathematical questions to the level of understanding and reasoning concepts of students is. Teachers need to study the learning preferences of each student by providing different (differentiated instruction) teaching in each mathematics learning given in the class. Determining the design and presentation of questions in mathematics is the teachers' initial key to improve the students' quality and logical reasoning. The purpose of this study is to design a mathematical learning module with instructions and questions according to students' individual variations in competencies in linear system at the SMK level. This study focuses on how to make instructions and questions design with module to improve understanding of variable
\end{abstract}


concepts, the principle of changing forms, interpreting problems and models into linear system and improving procedural reasoning and fluency. Each student can choose the instruction according to their interests, potentials, multiple intelligence and other aspects of the participants uniqueness. After the module is made, the module is validated by experts. Validation is carried out by 4 teachers. The result is very good. Next, product testing is done. The trials were carried out in X grade of Accounting for 4 times and in XI grade of Accounting for 2 times. The conclusions from the results of this study are: (1) The use of various forms of presentation with learning modules in the form of convenience that are used in various groups of students who have many individual variations in mathematics learning, (2) The use of various forms of presentation with learning modules students deepen their understanding, especially concepts, (3) the presentation of different forms of presentation with the learning module gives hope to students' thinking and punishment, (4) the final draft prototype can be reproduced to become teaching material in vocational schools, both at research sites and elsewhere, (5) Development of modules that can be used in mathematics learning for teachers to improve students' communication skills and mathematical problem solving

Keyword: Moduls, differentiated instruction, varians.

\section{PENDAHULUAN}

Dewasa ini dunia pendidikan di Indonesia semakin meningkat dan maju pesat, berkat kesadaran masyarakat itu sendiri akan pentingnya pendidikan. Begitupun halnya dengan matematika yang merupakan salah satu cabang ilmu yang memiliki arti luas. Sampai saat ini diantara para akhli matematika belum ada kesepakatan yang bulat untuk memberikan jawaban atas definisi matematika, maka akan ditemukan beragam gambaran hakikat matematika. Dari mulai matematika yang dipandang sebagai ilmu tentang struktur, matematika sebagai ilmu deduktif, matematika sebagai ilmu tentang pola dan hub ungan, matematika sebagai ilmu suatu seni dan bahasa, hingga matematika adalah ratunya ilmu sekaligus pelayan ilmu.

Ruseffendi (1988 : 23) mengatakan bahwa matematika terorganisasikan dari unsurunsur yang tidak didefinisikan, definisi-definisi, aksioma-aksioma, dan dalil-dalil di mana dalil-dalil setelah dibuktikan kebenarannya berlaku secara umum, karena itulah matematika sering disebut ilmu deduktif. Selain itu ada juga pendapat dari Johnson dan Rising (1972) yang menyatakan matematika adalah pola berpikir, pola mengorganisasikan, pembuktian yang logis, matematika itu adalah bahasa yang menggunakan istilah yang didefinisikan dengan cermat, jelas dan akurat representasinya dengan simbol dan padat, lebih berupa bahasa simbol mengenai ide dari pada mengenai bunyi. Lain halnya dengan Reys dkk (1984), matematika adalah telaahan tentang pola dan hubungan, suatu jalan atau pola berpikir, suatu seni, suatu bahasa dan suatu alat. Sedangkan Hasan Alwi (2002 : 723) dalam Kamus Besar Bahasa Indonesia (KBBI), matematika didefinisikan sebagai ilmu tentang bilangan, hubungan antara bilangan, dan prosedur operasional yang digunakan dalam penyelesaian masalah mengenai bilangan. Sedangkan menurut Sumardyono (2004: 28) 
mengatakan matematika sebagai seni yang kreatif. Penalaran yang logis dan efisien serta pembendaharaan ide-ide dan pola-pola yang kreatif dan menakjubkan, maka matematika sering pula disebut sebagai seni, khususnya merupakan seni berpikir krearif.

Pelajaran matematika perlu diberikan kepada semua peserta didik mulai dari sekolah dasar, hal ini dimaksudkan untuk membekali peserta didik dengan kemampuan berpikir logis, analitis, sistematis, kritis, dan kreatif, serta kemampuan bekerjasama (BSNP : 2006). Penulis mencoba memberikan materi pembelajaran matematika dengan menggunakan modul, sebab selama ini disetiap sekolah terutama di SMK buku pegangannya tidak ada. Walaupun ada bukan merupakan buku paket ataupun buku pegangan sebagaimana sekolah menengah atas (SMA). Setiap peserta didik mendapat buku pegangan satu-satu. Untuk buku pegangan di SMA tersebut menggunakannya bermacam-macam, selain buku paket merekapun menggunakan buku pegangan lainnya yang banyak beredar dari bermacan-macam penerbit. Sementara buku pegangan untuk SMK jurusan non-teknik dapat di hitung dan itupun ratarata untuk jurusan teknik..

Baru pada Kurikulum 2004 buku pegangan berupa buku paket ada yaitu dari BNSP untuk digunakan dalam pembelajaran dan itupun kurang mewakili. Apalagi pada Kurikulum 2013 buku paketnya disamakan dengan SMA yang sebenarnya sangat berbeda. Jika dilihat dari sumberdayananya dan tingkatan ekonomi untuk SMK dari tingkatan menengah kebawah. Sangat jelas sangat berpengaruh pada tingkat kemampuan atau kecerdasan para peserta didik. Sementara di SMK terdapat macam-macam jurusan yang berbeda-beda, yang intinya terbagi dua yaitu teknik dan non-teknik. Untuk SMK jurusan teknik itu terbagi lagi ada jurusan teknik, kesehatan, dll, sementara untuk SMK jurusan non-teknik ada jurusan Bisnis dan Manajemen, Sosial, Pariwisata, dll.

Ini semua merupakan suatu tantangan bagi penulis untuk membuat bahan ajar yang berupa modul, untuk mendesain soal matematika tentang materi sistem persamaan linear. Dalam penelitian ini yang dilandasi gagasan bahwa setiap peserta didik memiliki banyak keragaman dan variasi individu yang berbeda dalam memandang belajar matematikanya. Agar peserta didik memperoleh pemahaman konsep variabel, prinsip mengubah bentuk, menafsirkan permasalahan dan model ke dalam sistem persamaan linear dan penalaran dalam belajar matematika agar lebih baik sebagaimana yang diinginkan.

Cockroft (Shadiq, 2004 : 23) menyatakan bahwa perlunya para peserta didik belajar matematika dikarenakan bahwa matematika merupakan alat komunikasi yang sangat kuat, teliti dan tidak membingungkan. Depdiknas (Shadiq, 2004 : 20) menyatakan bahwa banyak persoalan atau informasi disampaikan dalam bahasa matematika, mengkomunikasikan 
gagasan dalam bahasa matematika justru lebih praktis, sistematis dan efisien, sehingga bahasa matematika merupakan bagian dari bahasa yang digunakan dalam masyarakat. Begitupun dalam pembuatan bahan ajar yang berupa modul, untuk memudahkan peserta didik belajar matematika. Juga untuk menunjang buku paket yang ada kurang dipahami oleh para peserta didik dari siswa-siswi SMK, sebab banyak yang tidak sesuainya bahkan soalsoal olimpiade ada didalamnya dan tidak dipahami terlalu tinggi untuk tingkat kemampuan siswa-siswi SMK. Apalagi tingkat kemampuan para peserta didik dari SMK sangat berbeda dengan peserta didik dari SMA.

Pada pembelajaran matematika selama ini, penulis sebagai pengajar terlebih dahulu memberikan motivasi kepada peserta didik untuk menghilangkan kecemasan-kecemasan yang sebelumnya dialami. Seperti anggapan selama ini bahwa pelajaran matematika merupakan pelajaran yang sulit dan menganggap bahwa matematika sebagai pelajaran yang membosankan. Meskipun pada kenyataannya yang terjadi banyak temuan yang didapat dari para peserta didik dalam pemahaman matematikanya masih jauh sebagaimana yang diharapkan, dikarenakan kecemasan-kecemasan yang pernah dirasakan dan beranggapan matematika seperti itu. Oleh sebab itu untuk menghilangkan kecemasan matematika itu sulit, penulis mencoba memberikan gambaran-gambaran lain untuk memudahkan belajar matematika. Pada materi sistem persamaan linear ini akan memberi suatu pilihan yang berbeda dengan desain soal yang berbeda dengan menggunakan modul pembelajaran.

Winkel (1996) menjelaskan bahwa modul merupakan suatu program belajar mengajar terkecil yang dipelajari oleh siswa sendiri kepada dirinya sendiri (self instruksional) setelah siswa menyelesaikan yang satu dan melangkah maju dan mempelajari satuan berikutnya. Menurut Ika Lestari (2012 : 6), modul merupakan bahan ajar yang ditulis dengan tujuan agar peserta didik dapat belajar secara mandiri tanpa atau dengan bimbingan guru, oleh karena itu, modul harus berisi tentang petunjuk belajar, kompetensi yang akan dicapai, isi materi pelajaran, informasi pendukung, latihan soal, petunjuk kerja, evaluasi, dan balikan terhadap hasil evaluasi. Modul sebagaimana pengertian diatas merupakan salah satu media cetak lainnya yang perbedaannya dapat dilihat dari ciri-ciri yang dimiliki oleh modul itu sendiri. Dari pendapat tentang modul diatas dapat disimpulkan bahwa modul merupakan salah satu media pembelajaran dalam bentuk buku paket mandiri yang meliputi serangkaian pengalaman belajar yang direncanakan dan disusun secara sistematis dengan tujuan membantu peserta didik. Dengan pemberian modul, peserta didik dapat belajar mandiri tanpa harus dibantu oleh guru. Peserta didik yang memiliki kecepatan belajar yang rendah dapat berkali-kali mempelajari setiap kegiatan belajar tanpa terbatas oleh waktu, sedangkan peserta didik yang kecepatan belajarnya 
tinggi akan lebih cepat mempelajari satu kompetensi dasar (Ika Lestari, 2012 : 6). Pada intinya, modul sangat mewadahi kecepatan belajar peserta didik yang berbeda-beda.

Bertolak dari uraian di atas, maka penulis tergerak untuk melakukan penelitian dengan mengangkat judul “ Desain Modul Pembelajaran Matematika Dengan Instruksi Dan Soal Sesuai Variasi Individu Siswa Pada Materi Sistem Persamaan Linear”.

Rumusan masalah yang dikaji dalam prnrlitian ini dirumuskan aebagai berikut:

Bagaimana membuat desain modul pembelajaran matematika dengan instruksi dan soal untuk meningkatkan pemahaman konsep, prinsip mengubah bentuk, menafsirkan permasalahan dan model ke dalam sistem persamaan linear serta meningkatkan penalaran, komunikasi, dan pemacahan masalah peserta didik pada pembelajaran matematika?

\section{METODE PENELITIAN}

\section{Desain Instruksi Dan Soal Matematika}

Penyajian desain instruksi dan soal matematika pada maateri sistem persamaan linear (SPL), mengacu pada empat gagasan untuk meningkatkan penalaran peserta didik dalam materi aljabar, meliputi: (1) memahami pola, hubungan, dan fungsi, (2) menyajikan dan menganalisis situasi dan struktur matematika menggunakan lambang aljabar, (3) menggunakan model matematika untuk menyajikan dan memahami hubungan kuantitatif, dan (4) menganalisis perubahan dalam berbagai konteks. Pengembangkan pola berpikir aljabar melalui desain instruksi dan soal dilakukan dengan cara memberikan permasalahan matematika. Permasalahan yang diberikan disusun untuk meningkatkan ketrampilan pemecahan masalah, ketrampilan menyajikan, dan ketrampilan penalaran.

Desain instruksi dan soal matematika pada maateri sistem persamaan linear (SPL), meliputi: (1) Insturksi dan penyajian soal dalam berbagai bentuk, (2) Gagasan pendukung desain instruksi dan penyajian soal dalam berbagai bentuk, (3) Penerapan berbagai bentuk penyajian dalam soal sistem persamaan linear, yaitu: (a) Instruksi dan soal dalam bentuk bahasa verbal, (b) Instruksi dan soal dalam bentuk visual, (c) Instruksi dan soal dalam bentuk model.

\section{Modul}

Modul adalah materi pelajaran yang disusun dan disajikan secara tertulis sedemikian rupa sehingga pembaca dapat menyerap sendiri materi tersebut dengan tanpa atau sesedikit mungkin membutuhkan bantuan dari orang lain. Depdiknas (2008: 8), bahan ajar tertulis 
sebaiknya dikembangkan sendiri oleh guru karena lebih bermanfaat jika dibandingkan dengan menggunakan buku cetak.

Modul-modul itu tidak sama panjangnya. Waktu atau periode yang diperlukan peserta didik untuk menyempurnakan sebuah modul dalam beberapa hal diperhitungkan secara mingguan dan bulanan pelajaran. Lamanya waktu yang diperlukan untuk menyelesaikan sebuah modul atau unit studi tergantung pada: (a) kemajemukan dan jumlah tujuan pelajaran di dalam modul itu, (b) tipe dan jumlah kegiatan belajar, (c) kemampuan peserta didik. Modul ditulis lebih rinci dibandingkan buku, isi modul harus sesuai dengan bidang pada jenjang dan kelas tertentu. Ada 2 jenis modul, yaitu: (1) Modul Self-Contained: Yang isinya lengkap sekali sehingga peserta menguasai pengetahuan yang dibutuhkan tanpa harus membaca sumber lain, (2) Modul Non Self-Contained: Yang isinya belum lengkap sehingga untuk menguasai pengetahuan yang dibutuhkan harus membaca sumber lain yang relevan.

\section{Model Pengembangan}

Penelitian yang akan digunakan oleh penulis adalah Perancangan Produk. Pada proses perancangan produk, peneliti harus menggunakan sebuah model perancangan untuk membuat rancangan produk awal. Oleh karena itu penelitian ini dikatakan penelitian pengembangan (Research and Development) karena menghasilkan sebuah bahan ajar cetak berupa modul pembelajaran. Penelitian pengembangan merupakan salah satu jenis penelitian yang sedang marak dilaksanakan oleh para peneliti dimana bukan untuk menguji teori, menguji hipotesis namun menguji dan menyempurnakan produk. Jenis penelitian ini sudah mulai diterapkan dalam penelitian dalam dunia pendidikan. Sebagaimana yang dikemukakan Borg and Gall (1979 : 624), educational research and development is a process used to develop and validate educational product.

Penelitian pengembangan pendidikan adalah sebuah proses yang digunakan untuk mengembangkan dan memvalidasi produk pendidikan, menurutnya ada 10 langkah dalam penelitian pengembangan tersebut. Begitupun menurut Sugiyono (2009 : 409) penelitian dan pengembangan terdiri dari 10 langkah, yaitu: (1) Potensi dan masalah. Penelitian harus berangkat dari potensi atau masalah. Potensi adalah segala sesuatu yang bila didayagunakan akan memiliki nilai tambah. Masalah adalah penyimpangan antara yang diharapkan dengan yang terjadi. Masalah dapat diatasi melalui penelitian pengembangan dengan cara meneliti sehingga dapat ditemukan suatu model, pola atau sistem penanganan terpadu yang efektif yang dapat digunakan untuk mengatasi masalah tersebut, (2) Pengumpulan data. Setelah 
potensi dan masalah dapat ditujukan secara faktual dan up to date, maka selanjutnya perlu dikumpulkan berbagai informasi yang dapat digunakan sebagai bahan untuk perencanaan produk sesuatu yang diharapkan dapat mengatasi masalah tersebut. Pengumpulan berbagai data yang diperlukan dalam perancangan produk, (3) Desain produk. Dalam bidang pendidikan, penelitian pengembangan menghasilkan produk yang diharapkan dapat meningkatkan produktivitas pendidikan yaitu lulusan yang berkualitas dan relevan dengan kubutuhan. Produk pendidikan misalnya kurikulun yang spesifik untuk keperluan pendidikan tertentu, metode mengajar, media pendidikan, buku ajar, modul, ompetensi tenaga kependidikan, sistem evaluasi dan lain-lain. Pembuatan rancangan produk awal yang akan dibuat lengkap dengan spesifikasinya yaitu modul.

\section{Validasi Desain}

Validasi desain merupakan proses kegiatan untuk menilai apakah rancangan produk itu secara raasional baik atau efektif. Dikatakan sacara rasional, karena validasi di sini masih bersifat penilaian berdasarkan pemikiran rasioanal, belum fakta di lapangan. Validasi desain dapat diadakan dengan menghadirkan beberapa pakar atau tenaga ahli yang sudah berpengalaman untuk menilai produk baru yang dirancang tersebut.

\section{Revisi Desain}

Setelah desain produk divalidasi melalui diskusi dengan para pakar dan para ahli lainnya, maka akan dapat diketahui kelemahannya. Kelemahan tersebut diperbaiki dengan cara merubah desain.

\section{Ujicoba Produk}

Dalam bidang pendidikan, desain produk harus dapat langsung diuji coba, setelah divalidasi dan revisi. Uji coba tahap awal dilakukan dengan simulasi penggunaan produk baru tersebut. Setelah disimulasikan maka dapat diuji cobakan pada kelompok yang terbatas. Pengujian dapat dilakukan dengan tujuan untuk mendapatkan informasi apakah produk baru tersebut efektif dan efisien atau dalam hal ini memberikan hasil yang lebih baik jika dibandingkan dengan produk lain. Untuk itu pengujian dapat dilakukan dengan eksperimen yaitu membandingkan efektifitas produk baru dengan produk lama. 
Revisi Produk

Apabila dalam pengujian produk di dapat hasil yang kurang memuaskan maka dapat direvisi lagi dan setelah direvisi maka perlu diuji cobakan lagi.

\section{Ujicoba Pemakaian}

Setelah uji coba terhadap produk berhasil maka selanjutnya produk tersebut diterapkan dalam lingkup yang lebih luas. Dalam pelaksanaannya, produk baru tersebut harus tetap di nilai kekurangan atau hambatan yang muncul guna untuk perbaikan lebih lanjut.

\section{Revisi Produk}

Revisi produk dilakukan apabila dalam pemakaian pada lembaga yang lebih luas terdapat kekurangan dan kelemahan. Dalam uji pemakaian, sebaiknya pembuat produk selalu mengevaluasi bagaimana kinerja produk. Evaluasi dilakukan untuk mengetahui kelemahan-kelemahan yang ada sehingga dapat digunakan untuk penyempurnaan dan pembuatan produk baru lagi.

\section{Produksi Massal}

Bila produk yang dihasilkan tersebut telah efektif dalam beberapa kali pengujian, maka produk tersebut dapat diterapkan pada lembaga pendidikan yang lain. Pada tahap produksi massal dalam hal ini tidak dilakukan oleh peneliti, karena bukan bagian dari penelitian ini. Tahap produksi hanya sebatas kebutuhan penelitian saja. Produksi produk hasil pengembangan ini dilakukan dengan mencetak modul berisi desain instruksi dan soal matematika pada materi sistem persamaan linear yang telah direvisi kemudian diberikan kepada pihak SMK Negeri 1 Kota Bandung untuk digunakan oleh guru matematika yang mengajar di kelas $\mathrm{X}$.

\section{HASIL DAN PEMBAHASAN}

Sesuai dengan permasalahannya, penelitian ini untuk menguji desain instruksi dan model soal matematika dengan menggunakan modul pada materi sistem persamaan linear (SPL). Hal ini dimaksudkan agar diperoleh hasil penelitian yang dapat meningkatkan efektifitas dan efisiensi pembelajaran. Dengan pengembangan model, pendekatan dan metode pembelajaran serta media belajar yang menunjang keefektifan pencapaian kompetensi peserta didik. Proses perkembangan model, pendekatan, modul, dan media 
pembelajaran perlu didokumentasikan secara rapi dan dilaporkan secara sistematis sesuai dengan kaidah penulisan yang mencerminkan originalitas.

Dalam penelitian inipun terjadi suatu proses. Pada proses penelitian ini, dilakukan uji coba modul dengan menggunakan langkah-langkah sebagai berikut:

\section{Draf I}

Modul pembelajaran matematika diujikan kepada 2 orang guru mata pelajaran matematika dan 10 orang peserta didik kelas XI Jurusan Akuntansi. Pertemuan pertama ini dilakukan untuk mengetahui sejauhmana materi sistem persamaan linear yang telah diberikan dipahami peserta didik. Para peserta didik diberikan penjelasan dan pengarahan bagaimana penggunaan modul ke satu serta penyelesaiannya. Dari penjelasan tersebut, dalam penggunaan modul dapat diselesaikan dengan ketentuannya tidak seperti pembelajaran biasa. Bahwa pembelajaran dengan modul dapat dikerjakan secepat mungkin sesuai dengan tingkat kemampuan peserta didik, artinya setiap peserta didik dalam penyelesaiannya tidak sama ada yang cepat dan ada yang lambat. Ada ketentuan jika telah mencapai minimal 75\% boleh melanjutkan ke kegiatan berikutnya. Pada draf I ini hasil yang diperoleh belum memuaskan.

Dikarenakan para peserta didik sudah agak lupa bahkan tidak ingat lagi, sebab materinya telah diajarkan satu tahun yang lalu artinya sudah berlalu. Beranggapan jika sudah diajarkan tidak perlu diingat kembali dan tak perlu dibahas kembali. Padahal sebenarnya untuk materi sistem persamaan linear kadang-kadang atau sesekali ada dipakai pada bahasan atau materi tertentu secara tidak langsung tanpa mereka sadari. Oleh karenanya, penulis menganalisis dari hasil perolehan dari draf I ada kebaikan dan ada kekurangannya setelah mereka selesaikan.

\section{Draf II}

Pada pertemuan ke dua ini, peserta didiknya masih sama yaitu peserta didik kelas XI Jurusan Akuntansi dengan tidak diikuti dua orang gurunya. Disinipun guru memberikan penjelasan dan pengarahan terlebih dahulu untuk mengevaluasi perbaikan kekurangan pada draf I apa-apa yang menjadi temuan.

Disini para peserta didik menyelesaikan sebagaimana biasanya sesuai dengan pengarahan yang telah disampaikan. Sebagaimana pada draf I, peserta didik menyelesaiakannya tidak bersamaan. Hasil yang diperoleh mulai menunjukkan peningkatan, 
meskipun masih ada kekurangan. Kekurangannya masih tetap seperti pada draf I, yaitu pada pecahan.

\section{Draf III}

Di pertemuan ke tiga ini, peserta didiknya tidak hanya kelas XI Jurusan Akuntansi akan tetapi dimulai juga untuk kelas $\mathrm{X}$ jurusan Akuntansi untuk memulai uji coba yang pertama. Jumlah pesertanya bertambah 30 orang peserta didik menjadi 40 orang peserta didik, namun untuk tempatnya tidak bersamaan.

Dalam penyelesaiannya bagi kelas XI dilakukan sabagaimana biasanya, artinya sudah mulai rutin. Tetapi bagi kelas $\mathrm{X}$, mereka baru memulai dan perlakuannya berbeda dengan kelas XI. Dalam penyampaiannya diterangkan terlebih dahulu sebagaimana kegiatan belajar mengajar. Disini terlihat antusias para peserta didik dalam mengikuti pembelajaran, meskipun sebenarnya untuk materi sistem persamaan linear sudah pernah dipelajari pada waktu di SMP. Namun menurut mereka ada bahasan yang menarik, yang tidak mereka temukan ketika di SMP.

Kesimpulan pada draf III untuk kelas XI masih ditemukan kekurangan-kekurangan sebagaimana draf II, yaitu masih di pecahan. Sedangkan di kelas X, kekurangannya tidak berbeda dengan kelas XI mengenai pecahan.

\section{Draf IV}

Pada pertemuan ke empat ini, peserta didiknya selain kelas X, kels XI, ada tim validator. Modul ini diperiksa oleh validator yang tenaga pendidik di SMK yang berpengalaman dan bekeahlian tentang bahan ajar metode pembelajaran di SMK.

Akhir dari uji coba ini, validator memberikan masukan dan hasil temuan untuk ditindaklajuti menjadi draf prototip modul final, kelas $\mathrm{X}$ diberi postes. Tim pakar yaitu validator yang dipilih sesuai dengan pertimbangan keahlian, kepakaran dan pengalaman dalam pembelajaran matematika. Dalam hal ini validasi yang dilakukan adalah validasi isi materi dan validasi desain soal pada modul.

Berdasarkan hasil penelitian, pengembangan pembelajaran matematika dengan menggunakan modul dapat meningkatkan motivasi belajar peserta didik terlihat dari hasil obsevasi selama pembelajaran. Berdasarkan hasil wawancara yang dilakukan pada peserta didik hampir semuanya mengatakan senang belajar menggunakan modul, selain mereka dapat menambah wawasan dengan informasi-informasi yang terdapat dalam modul juga 
dapat menuangkan gagasan dan ide. Karena lebih memudahkan peserta didik untuk lebih memahami konsep yang telah dikonstruksi yang dikaitkan dengan konteks nyata yang dikenal peserta didik. Konsep yang dikonstruksi pada peserta didik ditemukan sendiri oleh peserta didik. Begitupun dalam pembelajaran matematika yang sedang dilakukan para peserta didik.

Menurut Freudental (Gravemeijer, 1994 : 20) matematika merupakan aktivitas insani (human activities) dan pembelajaran matematika merupakan proses penemuan kembali. Ditambahkan oleh de Lange (Sutarto Hadi, 2005 : 19) proses penemuan kembali tersebut harus dikembangkan melalui penjelajahan berbagai persoalan dunia real. Masalah konteks nyata menurut Gravemeijer (1994: 123) merupakan bagian inti dan dijadikan starting point dalam pembelajaran matematika. Konstruksi pengetahuan matematika oleh peserta didik dengan memperhatikan konteks itu berlangsung dalam proses yang oleh Freudenthal dinamakan reinvensi terbimbing (guided reinvention).

Kemampuan memahami hubungan antar konsep, kematangan dalam bernalar dan keterlibatan secara aktif dalam pembelajaran merupakan bagian yang diperlukan dalam memecahkan masalah. Agar setiap peserta didik dapat membiasakan diri berargumen atas setiap ide atau gagasannya tidak lagi pasif atau hanya terdiam, tetapi dapat mengungkapkan kembali suatu masalah matematika dalam bahasa sendiri secara tertulis berdasarkan data atau bukti yang relevan. Hal ini sesuai dengan NCTM (Walle, 2007: 3) bahwa para siswa harus belajar dengan pemahaman, secara aktif membangun pengetahuan baru dari pengalaman dan pengetahuan sebelumnya.

Pembelajaran matematika dengan mendesain intruksi dan soal matematika menggunakan modul diantaranya, dapat memberikan kesempatan kepada peserta didik untuk lebih memahami persoalan matematika secara bertahap sesuai kesiapannya, dan guru dapat memberikan bantuan yang tepat kepada peserta didik berdasarkan respon dari peserta didik. Bahwa para peserta didik mampu menyelesaikan permasalahan-permasalahan yang terdapat pada modul, sehingga diperlukan perhatian yang lebih bagi guru dalam pembelajaran berikutnya. Agar kemampuan peserta didik dapat berkembang dan mandiri, maka peserta didik harus: (1) memahami masalah, meliputi kemampuan mengidentifikasi kecukupan data dan membuat pendekatan matematis dari suatu situasi atau masalah seharihari, (2) menyelesaikan masalah, meliputi kemampuan memilih dan menerapkannya strategi untuk menyelesaikan pendekatan atau masalah yang diberikan, (3) menjawab masalah, meliputi kemampuan menjelaskan atau menginterpretasikan hasil sesuai masalah yang diberikan, dan menuliskan atau memeriksa kebenaran hasil atau jawaban. 
Penggunaan berbagai bentuk penyajian pada dasarnya merupakan penjabaran dari dunia nyata menjadi kalimat matematika dalam persamaan, pertidaksamaan atau simbol melalui ungkapan tertulis, menggambar dan mengungkapkan bahasa simbolis dengan variabel serta menghubungkan bentuk kualitatif. Penyajian dengan berbagai bentuk ini dapat menjadi dasar bagi para peserta didik menghubungkan cara berpikirnya dengan penalaran matematika secara aljabar. Setiap peserta didik juga dapat mengembangkan penalaran matematika ketika menginterpretasikan persamaan dalam bentuk gambar, grafis atau bentuk penyajian simbolis menggunakan variabel.

Bentuk penyajian dalam merepresentasikan permasalahan matematika dapat dijelaskan dalam sistem pada gambar (1). Sistem ini menghadirkan matematika sebagai formulasi dalam bentuk simbol atau bahasa matematika dari dunia nyata/kontekstual. Proses matematisasi dari dunia nyata dan kontekstual menjadi simbol matematika melalui penyajian dalam bentuk model, gambar (tabel, grafik) dan bahasa verbal.

Proses ini diilustrasikan seperti pada gambar berikut ini:

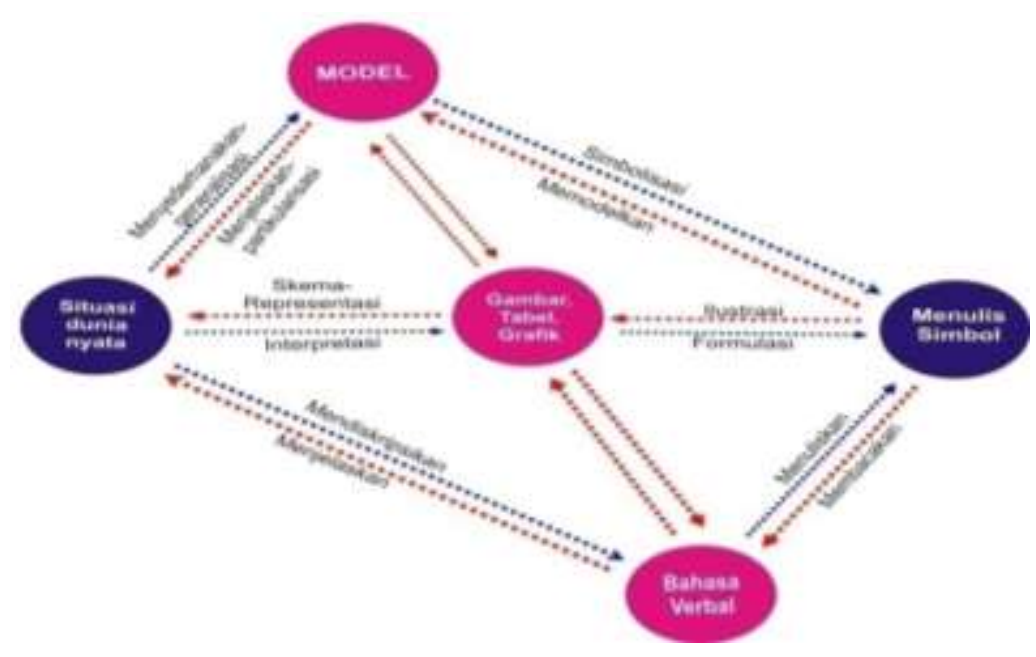

Gambar 1. Sistem penyajian

Hasil dari pola berpikir tersebut, melalui desain instruksi dan soal dilakukan dengan cara memberikan permasalahan matematika. Permasalahan yang diberikan disusun untuk meningkatkan ketrampilan pemecahan masalah (problem solving skills), ketrampilan menyajikan (representation skills) dan ketrampilan penalaran (quantitative reasoning skills), diharapkan para peserta didik mampu menyelesaikannya. Hubungan antara ketrampilan pemecahan masalah, ketrampilan menyajikan dan ketrampilan penalaran kuantitatif dengan gagasan mendasar dari aljabar.

Penerapan dari berbagai bentuk pengajian dalam desain instruksi dan soal matematika pada materi sistem persamaan linear mengacu pada empat gagasan, yaitu untuk 
meningkatkan penalaran peserts didik dalam materi aljabar yang rekomendasikan oleh Prinsip dan Standar Matematika Sekolah, NCTM yang meliputi: (1) Memahami pola, hubungan, dan fungsi, (2) Menyajikan dan menganalisis situasi dan struktur matematika menggunakan lambang aljabar, (3) Menggunakan model matematika untuk menyajikan dan memahami hubungan kuantitatif, (4) Menganalisis perubahan dalam berbagai konteks.

\section{KESIMPULAN}

Berdasarkan hasil penelitian dan pembahasan dalam penelitian ini, dapat disimpulkan beberapa hal yaitu: (1) Penggunaan berbagai bentuk penyajian dengan modul pembelajaran merupakan sarana yang efektif ketika digunakan pada berbagai kelompok peserta didik yang memiliki banyak variasi individu dalam belajar matematika, (2) Penggunaan berbagai bentuk penyajian dengan modul pembelajaran menjadikan fleksibilitas untuk menterjemahkan bentuk matematika memudahkan peserta didik memperdalam pemahamannya terutama konsep, (3) Penyajian berbagai bentuk penyajian yang berbeda dengan modul pembelajaran memberi harapan dalam menyesuaikan cara berpikir dan penalaran peserta didik., (4) Prototip draf final dapat diperbanyak untuk menjadi bahan ajar di SMK, baik ditempat penelitian maupun tempat lain, (5) Pengembangan modul dapat dijadikan alternatif dalam pembelajaran matematika bagi guru untuk meningkatkan kemampuan komunikasi dan pemecahan masalah matematis peserta didik.

\section{REFERENSI}

Arikunto, S. (2008). Dasar-dasar Evaluasi Pendidikan. Jakarta: Bumi Aksara.

Borg, W.R \& Gall, M.D (1979). Educational Research: An Introduction Fifth Edition. New York: Longman, Inc.

Breen, S \& O'Shea, A(2010). Mathematical Thingking and the Desaign. Irish Math. Sec. Bulletin 66 (2010), 39-49.

Creswell, J.W. (2010). Research Design Pendekatan Kualitatif, Kuantitatif, dan Mixed. Yogyakarta: Pustaka Pelajar.

Danim, S. (2010). Inovasi Pendidikan Dalam Upaya Peningkatan Profesionalisme Tenaga Kependidikan. Bandung: Pustaka Setia.

Dindyal, J. (2000). Algebraic thinking in geometry at high school level: students use of variables and unknowns. Singapore: National of Education.

Emzir. (2011). Metode Penelitian Pendidikan. Jakarta: Raja Grafindo.

Freudental, H. (1991). Revisiting Mathematics Education. Netherlands: Kluwer Academic Publishers.

Gardner, H. (2003). Kecerdasan Majemuk : Teori dalam Praktek. Alih bahasa: Arvin Saputra. Batam: Interaksara.

Gustafson, B. (2002). Survey of Instructional Devvelopment Models. New York: Eric Clearinghouse on Informations \& Tecknology. 
Hasan A, dkk. (2002). Kamus Besar Bahasa Indonesia. Jakarta: Balai Pustaka.

Kariadinata, R.(2010). Statistika Penelitian Pendidikan. Program Studi Pendidikan Matematika Fakultas Tarbiyah dan Keguruan UIN. Bandung.

Lestari, I. (2013). Pengembangan bahan Ajar berbasis Kompetensi Sesuai Dengan kurikulum Tingkat satuan Pendidikan. Padang.

Matlin, M.W. (1983). Cognition. Orlando, Florida: Harcourt Brace Publishers.

National Council of Teachers of Mathematics. (2000). Curriculum and evaluation standards for school mathematics. Reston, VA: Author.

. (2000). Principle and Standard for School Mathematics. Reston: The National Council of Teacher Mathematics, Inc.

Pusat Pengembangan Penataran Guru Matematika. (2000). Bahan Ajar Matematika SMK. Yogyakarta.

Richey, R. C. (2007). Design and Development Research. London: Lawrence Erlbaum Associates. Inc.

Romberg, T.A. (1992). Problematic Features of the School Mathematics Curriculum, in J. Philip (Ed.). Handbook of Research on Curriculum. New York: A Project of American Educational Research Association.

Ruseffendi, E.T. (1988). Pengantar Kepada Membantu Guru Mengembangkan Kompetensinya dalam Pengajaran Matematika untuk Meningkatkan CBSA. Bandung: Tarsito.

- (1991). Penilaian Pendidikan dan Hasil Belajar Siswa Khususnya dalam Pengajaran Matematika: Untuk Guru dan Calon Guru. Bahan Kuliah: Tidak diterbitkan.

(1998). Statistika Dasar untuk Penelitian Pendidikan. Semarang.IKIP Semarang Press.

. (2005). Dasar-dasar Penelitian Pendidikan dan Bidang Non Eksakta Lainnya. Bandung: Tarsito.

(2006). Pengantar Kepada Membantu Guru Mengembangkan Kompetensinya Dalam Pengajaran Matematika untuk Meningkatkan CBSA. Bandung. Tarsito.

Santrock, J.W. (2007). Educational psychology ( $2^{\text {nd }}$ ed). Dalas: McGraw-Hill Company, Inc.

Sax, G. (1997). Principle of Educational and Psychological Measurement and Evaluation (4th ed.). Belmont, CA: Wadsworth.

Shadiq, F. (2004). Penalaran, Pemecahan Masalah dan Komunikasi Dalam Pembelajaran Matematika. P4TK Matematika Yogyakarta.

Siegel, S. (1997). Statistik Non Parametrik untuk ilmu-ilmu Sosial. Jakarta.

Sternberg, R.J. (2000). Intelligence: The triarchic theory of intelligence. In J.W. Gutherie (Ed), Encyclopedia of Education ( $2^{\text {nd }}$ ed). New York: Macmilan.

Sudjana, (2005). Metoda Statistika. Bandung. Tarsito.

Sugiyono, (2007). Metode Penelitian Pendidikan (Pendekatan kuantitatif, kualitatif dan $R$ $\& D)$ Bandung: Alfabeta.

(2008). Metode Penelitian Pendidikan (pendekatan kuantitatif, kualitatif dan $R \& D)$. Bandung: Alfabeta.

. (2009). Metode Penelitian Pendidikan (pendekatan kuantitatif, kualitatif dan $R \& D)$. Bandung: Alfabeta.

(2010). Metode Penelitian Pendidikan (pendekatan kuantitatif, kualitatif dan $R \& D)$. Bandung: Alfabeta.

Suh, J \& Moyer, P.S. (2007). Developing students reperentational fluency using virtual and physical algebra balances. USA: George Mason University. 
Suherman, (1990). Petunjuk Praktis untuk Matematika Evaluasi Pendidikan Matematika. Bandung: Wijayakusumah 157.

JICA-UPI

(2001). Strategi Pembelajaran Matematika Konteporer. Bandung. (2003). Evaluasi Pembelajaran Matematika. Bandung. UPI.

Sumardyono. (2004). Karakteristik Matematika dan Implikasinya terhadap Pembelajaran Matematika. Yogyakarta: Depdiknas.

Subino. (1997). Konstruksi dan Analisis Tes. Jakarta: Depdikbud.

Soenarto, (2008). Penelitian Pengembangan Research \& Development (R\&D) Sebagai Upaya Peningkatan Kualitas Pembelajaran. Makalah disajikan dalam Sarasehan Metodologi Penelitian, di Program PascaSarjana UNY.

Swetz, F \& Hartzler, J.S. (1991), Mathematical Modeling in the Secondary School Curriculum. NCTM.

Taskin, A.G \& Kirikci, Mustafa. Pre-Algebra 2. Istanbul, Turki: Zambak Yakinlari.

Walle, J.A.V. (2002). Sekolah Dasar dan Menengah Matematika Pengembangan Pengajaran. Jakarta: Erlangga.

Walle, J.A.V.D. (2007). Elementary and Middle School Mathematics (Sixth Edition). By Pearson Education, Inc.

Wardhani, S. (2004). Permasalahan konstektual mengenalkan bentuk aljabar SMP. Yogyakarta: PPPGM Depdiknas. 